\title{
Primož Šterbenc: Zahod in muslimanski svet: akcije in reakcije
}

\author{
Ljubljana: Fakulteta za družbene vede, Založba FDV, 2011, 342 strani
}

V prvem desetletju enaindvajsetega stoletja smo bili priča številnim dogodkom, ki so opozorili na zapletene odnose med Zahodom in muslimanskim svetom. Grozljivi teroristični napad na Svetovni trgovinski center v New Yorku, ameriška vojna v Iraku, protesti mladih $\mathrm{v}$ Tuniziji in Egiptu ter izzivanje muslimanskih vernikov s strani zahodnih medijev z žaljivim prikazovanjem Mohameda izkazujejo eno največjih težav človeštva: odsotnost dialoga zaradi nezmožnosti vživljanja drug v drugega. Globlji zgodovinski, ideološki, družbeni in politični razlogi tega medsebojnega nezaupanja in nerazumevanja $\mathrm{v}$ medijih niso upoštevani.

Doktor Primož Šterbenc se je z najnovejšo knjigo Zahod in muslimanski svet: Akcije in reakcije posvetil tej zapleteni znanstveni nalogi. Pod analitični drobnogled je vzel vpliv religijskega dejavnika v politiki zahodnega in muslimanskega sveta.

Če hočemo bolje razumeti najnovejše odzive muslimanskega sveta na ravnanja Zahoda, je pomembno, da bolje spoznamo vzroke ponovnega vzpona islama $\mathrm{v}$ zadnjih štiridesetih letih, uvodoma pojasni avtor. V sedemdesetih letih dvajsetega stoletja se je znova začela krepiti vloga religije v osebnem, javnem, predvsem pa političnem življenju muslimanov. Na politično sceno so v muslimanskih državah takrat vdrle islamistične stranke ter zmerna in skrajna fundamentalistična gibanja. Pri svojem delovanju so poudarjala pomen islama in s tem religijske identitete $\mathrm{v}$ politiki.

Vzpon političnega islama je bil odziv na modernizacijo, urbanizacijo in marginalizacijo velikega števila muslimanov. Ti procesi so povzročili razpad tradicionalnih skupnostnih identitet in vrednostnih sistemov. Med ljudmi so zavladale odtujenost, družbena dezorientiranost in odsotnost smisla. Toda muslimani se svoje vere niso oprijeli samo zaradi negativnih vidikov modernizacije. Bili so tudi nezadovoljni s svojimi sekularnimi političnimi elitami. Te so bile neuspešne pri vpeljevanju demokracije in reševanju gospodarskih problemov. Bile so nekakšne ujetnice sekularnih politik iz obdobja evropskega kolonializma, ki so jih še vedno uresničevale. Muslimane je razjezilo, da je bil sekularizem izrabljen predvsem za izrivanje islama iz javnega življenja, zato je vnovičen vzpon islama "posledica (samo) 
obrambnega impulza oziroma reakcije muslimanskega prebivalstva na percipirano dominacijo Zahoda. Podrejenost in izkoriščanost muslimanskega sveta, kot sta obstajali v kolonialnem obdobju, naj bi se namreč v bolj prikriti obliki ohranjali skozi perfidno zahodno neokolonialno dominacijo $\mathrm{v}$ času formalne neodvisnosti muslimanskih držav«, pojasnjuje avtor.

Doktor Šterbenc razkriva nekatera najbolj problematična ravnanja zahodne mednarodne skupnosti v sodobnem času, ki jih veliko muslimanov dojema kot težnje k vnovični dominaciji Zahoda. Muslimanski svet ni enoten blok. Na svetu je več kot petdeset muslimanskih držav z raznoterimi kulturami in različnimi stopnjami razvoja. Islam je res najmlajša od velikih religij, toda leta 2010 je štela že 1,6 milijarde pripadnikov (23,4 odstotka svetovnega prebivalstva). Do leta 2030 naj bi število muslimanov naraslo na 2,2 milijarde (26,4 odstotka svetovnega prebivalstva).

Doktor Šterbenc zagovarja tezo, da na politiko v muslimanskem svetu pomembno vpliva religija, ki je zadobila obrambno, nacionalistično vlogo, ni samo vez posameznika z nadnaravnim kot običajno. Vzpon islama je zato smiselno razlagati s konceptom kulturne obrambe, kot ga je razvil sociolog religije Steve Bruce, na katerega se doktor Šterbenc pogosto sklicuje.

Ob negativnih vidikih modernizacije, ki jih je izkusil muslimanski svet, je treba upoštevati tudi prepričanje muslimanov, da Zahod prikrito izvaja agresivno neokolonialno politiko. Doktor Šterbenc dokazuje, da Zahod svoj »novodobni kolonializem« izraža z vsiljevanjem neoliberalnega gospodarskega modela razvoja muslimanskemu svetu, in sicer z vojaškimi intervencijami. Primer tega je bil napad na Irak, ki so ga vodile ZDA.

$\mathrm{V}$ prvem delu knjige doktor Šterbenc bralca seznani z različnimi definicijami in vlogami religije ter podrobneje oriše zgodovinski razvoj teorije sekularizacije, osrednje poudarke družboslovnih klasikov in burno razpravo sociologov religije o (ne)pravilnosti njene teze od začetka sedemdesetih let do zdaj. Zanimiva je bila "reakcija« družboslovcev na vzpon islama v osemdesetih letih. Avtor je mnenja, da je preuranjeno pritrditi sociologom religije, ki so bili prepričani, da muslimanski svet dokazuje napačnost sekularizacijske paradigme, ker modernizacija v tem delu sveta ni takoj vodila k zmanjšanju pomena religije. Vendarle je prišlo do »delne sekularizacije« v smislu diferenciacije. Nekatera sekularna področja so se osamosvojila od verskih institucij in norm celo v najbolj islamiziranih državah. Religija ni narekovala delovanja pravnega, političnega in ekonomskega sistema. Modernizacijo $\mathrm{v}$ muslimanskih državah lahko dojamemo kot nedokončan proces. 
V drugem delu knjige avtor prikaže zgodovino širjenja islama po svetu od prve muslimanske skupnosti do današnjega časa. Predstavi osrednje poudarke islamske monoteistične doktrine in pomen preroka Mohameda za muslimane. Znova poudari, da krepitev islama ni samo posledica krize identitete. Predvsem je izraz odpora muslimanov proti politiki Zahoda, ki ima globlje zgodovinske korenine. Ne gre podcenjevati zgodovinskega spomina muslimanov na slabe izkušnje z Zahodom in njegove uničevalne križarske vojne, pa na evropski kolonializem, imperializem in neokolonializem. Zato je med številnimi muslimani nenehno navzoč strah, da jim bo Zahod znova poskusil vsiliti svojo vladavino. Osrednja nevralgična točka zaostrovanja medsebojnih odnosov ostaja nerešeno vprašanje Palestine, politično izključevanje muslimanov ter nasilni vojaški vdori Zahoda v muslimanski svet, s katerimi hoče Zahod potešiti svoje naftne in druge geostrateške interese. Doktor Šterbenc pojasnjuje, da je preračunljiva politika zahodne mednarodne skupnosti odgovorna za marginalizacijo muslimanskih držav. Zato se muslimani zatekajo k ponovnemu poudarjanju religijske identitete. Religijo dojemajo kot sredstvo lastne kulturne obrambe, ki varuje njihove družbene in kulturne institucije.

V tretjem delu se avtor živahno vživi v etične vzgibe srditega odpora muslimanskega sveta vsiljevanju neoliberalne ekonomske politike. Tega je predvidel tudi avtor razvpite teze o koncu zgodovine, konservativni politolog Francis Fukuyama.

Ko je knjiga doktorja Šterbenca izšla, je minilo že leto dni od protestov v Tuniziji in Egiptu. Nasprotno od medijskih komentarjev, da je šlo za upore proti samodržcem in "facebook revolucijo«, doktor Šterbenc natančneje pojasni vzrok izbruha nezadovoljstva brezpravnih, v revščino in bedo pahnjenih mladih. Tunizija in Egipt sta bila več desetletij zvesti uresničevalki neoliberalnih ukrepov Mednarodnega denarnega sklada, ki so poglobili družbeno in ekonomsko neenakost. Ne samo tradicionalno samodrštvo, tudi zahodne institucije multilateralnega sistema svetovne trgovine so pomembno prispevale $\mathrm{k}$ »demokratičnemu primanjkljaju« v omenjenih državah.

Zahodu je muslimanski svet trn $\mathrm{v}$ peti, ker predstavlja edino resno opozicijo neoliberalizmu, saj lahko razvije svoj družbeno-ekonomski razvojni pristop. Zanj je značilno izrazito poudarjanje vloge etike $\mathrm{v}$ gospodarstvu (moralna ekonomija). Podrobneje ga opisuje islamska sveta knjiga Koran. Drugače razume vlogo posameznika, ki naj deluje za skupnost, družbo in gospodarstvo, ne samo za svoj egoistični, pohlepni interes. Po Koranu je pohlep nesprejemljiv. Tudi država mora usmerjati gospodarstvo, ne samo trg. Avtor predstavi uveljavljanje nekaterih rešitev; islamsko bančništvo, ki poudarja dajanje brezobrestnih posojil, davek na bogastvo in dohodek - zakat. Te rešitve v praksi sicer niso najbolj zaživele, a treba je priznati njihovo izvirnost. Hkrati se je treba zavedati, pravi pakistanski ekonomist Syed Nawab Haider Naqvi, da je treba 
razlikovati med idealom islamske družbe in njegovim nasprotjem, tipičnim zdajšnjim muslimanom. Četudi bogati, bi moral pri svojem vsakdanjem ekonomskem ravnanju upoštevati etiko, pravi Naqvi.

Islamska ekonomska znanost se razlikuje od zahodne neoklasične ekonomske znanosti. S svojo normativnostjo hoče muslimane spodbuditi predvsem k etičnemu ekonomskemu ravnanju, medtem pa si druga domišlja, da ima pravico zavladati svetu. Doktor Šterbenc se nato vrne k očetu moderne ekonomije Adamu Smithu in njegovi teoriji moralnih čustev, doktrinarni utemeljitvi zahodnega ekonomskega egoizma. Tudi ta utemeljitev je nastala na verski podlagi, dokazuje avtor. Očitno je, da so tudi izvori zahodne moderne ekonomske znanosti teološki, nesekularni. Ali je mogoče govoriti o popolni osamosvojitvi ekonomije od religije? Ni skrivnost, da je prav religija najbolj pripomogla k uveljavitvi kapitalizma v Angliji in drugod po Evropi. Če vsako gospodarstvo temelji na verskih prepričanjih, se avtor sprašuje, ali bi bilo mogoče upoštevati pristope obeh svetov. Svet se je leta 2008 znašel v strahoviti finančni, gospodarski, politični in etični krizi. Ta kriza je »razgalila vse tisto, pred čemer ostro svari islamski vrednostni družbeno-ekonomski nauk. Delovanje pohlepnih, sebičnih svobodnih posameznikov, ki se ne zavedajo posledic svojih ravnanj za družbo, skupnost. "Prepuščanje gospodarstva zgolj svobodnemu trgu in omejevanje države dopušča špekulacije $\mathrm{z}$ navideznim denarjem, namerno ustvarjanje brezposelnosti in vzpostavljanje neravnotežja do skrajnosti. Pri iskanju rešitev iz krize bi odločevalce zato lahko navdihnil islamski pristop, ki poudarja socialno pravičnost.

V sklepnem, četrtem poglavju avtor s konceptom kulturne obrambe pojasni tudi državljansko vojno v Iraku. Predstavi, kako so jo zanetili Američani s klasično brutalno kolonialno okupacijo. S prekomerno uporabo sile so kršili pravice uporniškim sunitom in hkrati nastopali kot krščanski misijonarji, medtem pa podžgali stare zgodovinske zamere med iraškimi suniti in šiiti. Pri obojih so spodbudili krepitev religijske identitete in medsebojno nasilje. Vpliv religije na izbruh nasilja v Iraku je avtor pojasnil tudi s tako imenovanim konstruktivističnim pristopom ter s konceptoma sektaške države in eksistenčne varnosti.

Doktor Primož Šterbenc je knjigo Zahod in muslimanski svet: Akcije in reakcije napisal z vednostjo redkih politologov o skrajni miselni revnosti pojasnjevalne moči realistične teorije mednarodnih odnosov, predvsem njenih, največkrat iz fizike prenesenih kategorij, kot sta moč in sila, ki se jima pridružita država in nacionalni interes. To so kategorije, ki ne samo silovito poenostavljajo dojemanje stvarnosti, v mednarodni politiki služijo predvsem spodbujanju nasilja in vojn, onemogočajo kakršenkoli smiseln dialog med dvema navidezno civilizacijsko razklanima deloma sveta, kakršnokoli razumevanje drug drugega. 
Zavedanje pomembnosti religioznega dejavnika je, kot nakazuje avtor, nujno za vzpostavljanje enakopravnejšega odnosa med zahodnimi in muslimanskimi državami. Šterbenčeva najnovejša knjiga bi lahko zato postala koristno vodilo slovenskim vladam, ko se vključujejo v mednarodne diplomatske in vojaške misije, če že ne želji po širjenju polja tolerance in izobraževalnega interesa v širši javnosti. S pristopom sociologije religije je avtor vsebinsko obogatil politologijo mednarodnih odnosov. Upamo, da bo svoja znanstvena spoznanja nadgradil še z obiskom muslimanskih držav. 